\title{
COMPARATIVE STUDY ON THE IMPLEMENTATION OF COMBAT SPORTS - MARTIAL ARTS - IN THE PHYSICAL TRAINING OF MILITARY STUDENTS
}

\author{
Fabiana MARTINESCU-BĂDĂLAN \\ "Nicolae Bălcescu" Land Forces Academy, Sibiu, Romania \\ martinescu-fabiana@yahoo.com
}

\begin{abstract}
In the current context, martial arts continue to evolve and constantly develop, capturing the attention and the interest of the population of the entire world, the branch of these being diversified, offering individuals the possibility to be practiced, even by those with physical or mental disabilities. Nowadays, the large categories of armed forces of the world use martial arts as part of general physical training, with the purpose of self-defence against the enemy, discipline, improved physical and mental condition, improvement of the ability of the military to adapt to harsh conditions, as well as fighting without using weapons.
\end{abstract}

KEYWORDS: physical training, military students, martial arts

\section{Introduction}

Considering the two categories of research - fundamental and applicative, the organizational diagnosis is found as a subdivision of the applied research, this summing up fundamental scientific knowledge as well as empirical knowledge.

When we use the term diagnosis we refer to those "investigations done on an organization or an organizational subsystem, which use concepts of behavioural sciences, which aim to examine the current state of the organization, in order to make available to clients that relevant and valid information needed to increase the efficiency of the organization" (Harrison \& Shirom, 1999, p. 83).

Martial arts are primary forms of combat, transformed into a contemporary era in sports, self-defence, but also as a hobby.

Courage defines the leader who, despite the risks, has the initiative to follow and apply an idea. Martial arts influences and accustoms the newcomer to leaving the comfort zone from an early age, and gives them decision-making power in terms of their own actions, so that they can become a decision-maker.

Confidence is "the belief that you can successfully perform a desired action" (Weinberg \& Gould, 1999, p. 7). The lack of confidence in one's abilities represents the inability to follow your own decisions, a factor that makes it impossible for subordinates to rely on the superior's abilities and competences. Self-confidence is gained through a continuous confrontation with one's own limits, by making decisions in unfavourable or difficult situations, by subjecting the individual to physical and mental pressures, areas that martial arts combine and correlate perfectly. These disciplines can be used to increase the confidence in the own forces as well as the efficiency of the students. "People who are confident have learned to 
elucidate the dangerous and stressful situations they have encountered throughout their lives. Due to the nature of the martial arts, namely to deal with stressful situations, military students learn to control their negative emotions such as fear, doubt and anger" (Howell, 2003, p. 31). The selfcontrol acquired through these practices is responsible for increasing the level of confidence in one's own abilities.

Through this research method, the aim is to discover and analyze the availability of military students of the "Nicolae Bălcescu" Land Forces Academy in Sibiu and those of "General Milan Rastislav Štefánik" Academy of Armed Forces to practice combat sports as part of general physical training. Thus, the research conducted is applicative, of diagnostic type.

In the physical training process, the aim is to increase the level of activity at the level of the locomotor system, which ensures the need for general and specific training in the work-out process, and develops the physical qualities: strength, speed, endurance, flexibility, ability to coordinate, as well as the ability to demonstrate physical skills under competitive conditions, their accumulated improvement and manifestation (Achim, 2005).

Regardless of age, the practice of martial disciplines brings a surplus of force to the experts. At the same time, they discover the possibility of freeing themselves from the negative energy acquired during the day or week, through different methods and exercises such as meditation, training (sparing), mobility (stretching), etc. (Okazaki, 2009).

\section{Research Objectives}

$>$ identifying the preferences of military students to practice combat sports as part of the academic training;

$>$ recognition of the readiness of military students to take part in such courses; delimiting the positive and negative influences and benefits of practicing contact sports according to the students perspective.

\section{Research Methodology}

\subsection{Research Methods}

The questionnaire represents the instrument preferred by most sociologists in conducting quantitative level psychosociological research. The specialized literature of the questionnaire is defined as " a set of written and possibly imaginary questions, ordered logically and psychologically, which, through the administration by the survey operators and the self-administration, determines from the part of the persons in the investigation answers that are to registered in writing" (Chelcea, 2004, p. 105).

I believe that this study can be useful to the Land Forces Academy, obtaining the majority of students' opinion regarding the introduction of combat sports into the academic program, bringing a categorical benefit to the general physical training.

At the same time, I used this research method because the information obtained can be quantitative and qualitative, being able to be detailed in function of certain criteria, thus facilitating the in-depth knowledge of some aspects related to the importance of the physical training, the need for specialized trainers, and the influence of martial arts on the physical and mental health.

\subsection{The Research Sample}

The research was carried out on a sample of 200 students, 100 from the "Nicolae Bălcescu" Land Forces Academy in Sibiu (LFA) and 100 from the "General Milan Rastislav Štefánik" Academy of Armed Forces, from the second and third year of studies, of the years II and III, belonging to both combat and support military branches. 


\section{Processing and Analyzing the} Results

In order to complete the questionnaires, consisting of 21 items, the subjects responded by marking with $\mathrm{X}$ the option indicating the intensity of the agreement or disagreement with these statements, their responses being further on quantified and analyzed.
The subjects had to choose between the following options corresponding to the Likert scale: to a very small extent - 1 point; to a small extent - 2 points; on average -3 points; to a large extent -4 points; to a very large extent -5 points.

Table no. 1

Average scores to the questionnaires of "Nicolae Bălcescu” Land Forces Academy

\begin{tabular}{|c|c|c|c|c|c|c|c|c|}
\hline \multirow[b]{2}{*}{ ITEM } & \multicolumn{5}{|c|}{ Number of answers } & \multirow[b]{2}{*}{ TOTAL } & \multirow[b]{2}{*}{$\begin{array}{l}\text { Average } \\
\text { score }\end{array}$} & \multirow[b]{2}{*}{$\begin{array}{l}\text { No. of } \\
\text { questionnaires }\end{array}$} \\
\hline & $\begin{array}{l}\text { to a very } \\
\text { small } \\
\text { extent } \\
\text { (1) }\end{array}$ & $\begin{array}{l}\text { to a } \\
\text { small } \\
\text { extent } \\
\text { (2) }\end{array}$ & $\begin{array}{l}\text { average } \\
\text { (3) }\end{array}$ & $\begin{array}{l}\text { to a large } \\
\text { extent } \\
\text { (4) }\end{array}$ & $\begin{array}{l}\text { to a very } \\
\text { large } \\
\text { extent } \\
\text { (5) }\end{array}$ & & & \\
\hline 1 & 0 & 0 & 1 & 30 & 69 & 468 & 4,68 & 100 \\
\hline 2 & 0 & 1 & 4 & 21 & 74 & 468 & 4,68 & 100 \\
\hline 3 & 7 & 30 & 44 & 17 & 2 & 277 & 2,77 & 100 \\
\hline 4 & 3 & 6 & 13 & 55 & 23 & 389 & 3,89 & 100 \\
\hline 5 & 4 & 9 & 25 & 45 & 17 & 362 & 3,62 & 100 \\
\hline 6 & 4 & 2 & 34 & 48 & 12 & 362 & 3,62 & 100 \\
\hline \multicolumn{9}{|c|}{ Section 2 of the questionnaire } \\
\hline 7 & 20 & 27 & 35 & 17 & 1 & 252 & 2,52 & 100 \\
\hline 8 & 2 & 15 & 18 & 31 & 34 & 380 & 3,80 & 100 \\
\hline 9 & 0 & 4 & 22 & 37 & 37 & 407 & 4,07 & 100 \\
\hline 10 & 1 & 4 & 25 & 39 & 31 & 395 & 3,95 & 100 \\
\hline 11 & 1 & 5 & 17 & 39 & 38 & 408 & 4,08 & 100 \\
\hline 12 & 0 & 4 & 15 & 39 & 42 & 419 & 4,19 & 100 \\
\hline 13 & 1 & 2 & 22 & 39 & 37 & 412 & 4,12 & 100 \\
\hline 14 & 1 & 2 & 15 & 38 & 44 & 422 & 4,22 & 100 \\
\hline 15 & 0 & 6 & 19 & 28 & 47 & 416 & 4,16 & 100 \\
\hline \multicolumn{9}{|c|}{ Section 3 of the questionnaire } \\
\hline 16 & 0 & 1 & 16 & 43 & 40 & 422 & 4,22 & 100 \\
\hline 17 & 1 & 4 & 13 & 30 & 52 & 428 & 4,28 & 100 \\
\hline 18 & 1 & 4 & 31 & 44 & 20 & 378 & 3,78 & 100 \\
\hline 19 & 0 & 6 & 18 & 41 & 35 & 405 & 4,05 & 100 \\
\hline 20 & 3 & 11 & 14 & 46 & 26 & 381 & 3,81 & 100 \\
\hline 21 & 0 & 3 & 23 & 30 & 44 & 415 & 4,15 & 100 \\
\hline
\end{tabular}

The questionnaire was structured on three parts, in order to be able to separate the factors of interest as follows: highlighting the importance of physical training, the importance of practicing martial arts by military students, and the external factors acting on physical training. 
Table no. 2

Results of the questionnaire applied to the students of the "General Milan Rastislav Štefánik" Academy of Armed Forces

\begin{tabular}{|c|c|c|c|c|c|c|c|c|}
\hline \multirow[b]{2}{*}{ ITEM } & \multicolumn{5}{|c|}{ Number of answers } & \multirow[b]{2}{*}{ TOTAL } & \multirow[b]{2}{*}{$\begin{array}{l}\text { Average } \\
\text { score }\end{array}$} & \multirow[b]{2}{*}{$\begin{array}{l}\text { No. of } \\
\text { questionnaires }\end{array}$} \\
\hline & $\begin{array}{l}\text { to a very } \\
\text { small } \\
\text { extent } \\
\text { (1) }\end{array}$ & $\begin{array}{l}\text { to a small } \\
\text { extent } \\
\text { (2) }\end{array}$ & $\begin{array}{c}\text { average } \\
\text { (3) }\end{array}$ & $\begin{array}{c}\text { to a } \\
\text { large } \\
\text { extent } \\
(4)\end{array}$ & $\begin{array}{c}\text { to a very } \\
\text { large } \\
\text { extent } \\
(5)\end{array}$ & & & \\
\hline 1 & O & 1 & 8 & 32 & 59 & 449 & 4,49 & 100 \\
\hline 2 & $\mathbf{0}$ & 2 & 9 & 29 & 60 & 447 & 4,47 & 100 \\
\hline 3 & 7 & 22 & 52 & 19 & $\mathbf{0}$ & 283 & 2,83 & 100 \\
\hline 4 & 1 & 7 & 21 & 56 & 15 & 377 & 3,77 & 100 \\
\hline 5 & 4 & 10 & 24 & 47 & 15 & 359 & 3,59 & 100 \\
\hline 6 & 2 & 7 & 30 & 39 & 12 & 322 & 3,22 & 100 \\
\hline \multicolumn{9}{|c|}{ Section 2 of the questionnaire } \\
\hline 7 & 19 & 21 & 45 & 15 & $\mathbf{0}$ & 256 & 2,56 & 100 \\
\hline 8 & 2 & 17 & 16 & 37 & 28 & 372 & 3,72 & 100 \\
\hline 9 & 1 & 8 & 18 & 47 & 26 & 389 & 3,89 & 100 \\
\hline 10 & 1 & 8 & 22 & 50 & 19 & 370 & 3,70 & 100 \\
\hline 11 & 0 & 11 & 23 & 38 & 28 & 377 & 3,77 & 100 \\
\hline 12 & $\mathbf{0}$ & 5 & 16 & 54 & 25 & 399 & 3,99 & 100 \\
\hline 13 & $\mathbf{0}$ & 8 & 25 & 41 & 26 & 385 & 3,86 & 100 \\
\hline 14 & 3 & 9 & 22 & 37 & 29 & 380 & 3,80 & 100 \\
\hline 15 & 1 & 13 & 27 & 28 & 31 & 375 & 3,75 & 100 \\
\hline \multicolumn{9}{|c|}{ Section 3 of the questionnaire } \\
\hline 16 & $\mathbf{0}$ & 5 & 21 & 49 & 25 & 394 & 3,94 & 100 \\
\hline 17 & 1 & 9 & 19 & 35 & 36 & 396 & 3,96 & 100 \\
\hline 18 & 3 & 13 & 34 & 36 & 14 & 3,45 & 3,45 & 100 \\
\hline 19 & 1 & 21 & 28 & 24 & 26 & 353 & $\mathbf{3 , 5 3}$ & 100 \\
\hline 20 & 2 & 13 & 32 & 32 & 21 & 358 & 3,58 & 100 \\
\hline 21 & 1 & 8 & 21 & 36 & 34 & 394 & 3,94 & 100 \\
\hline
\end{tabular}

The first item of the questionnaire, namely: "Do you consider that physical training is important?" has the purpose of determining the degree of conviction of the students in terms of their physical training. An average score of 4.68 was obtained for this question (maximum possible being 5)

Q1. Do you consider that physical training is important? (AFT Students)

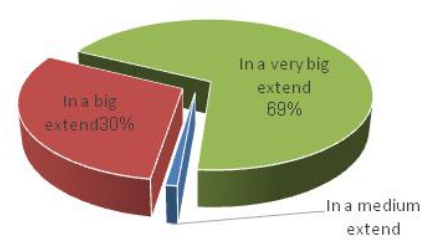

for the students of the "Nicolae Bălcescu" Land Forces Academy and of 4.49 for the students of the "General Milan Rastislav Štefánik" Academy of Armed Forces for the answers "to a large extent" and "to a very large extent".

Q1. Do you consider that physical training is important?

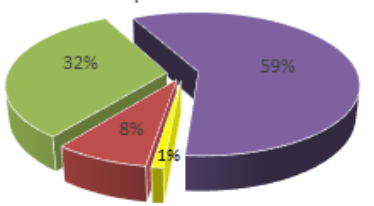

Figure no. 1: The answers of the students expressed in percentage to the question no. 1 
Items no. 2 , no. 4 , no. 5 and no. 6 refer to the conditions in which the physical training is carried out and to the its need to the military's life. Regarding the conditions for the preparation of the training, the military students appreciated that it is carried out according to acceptable

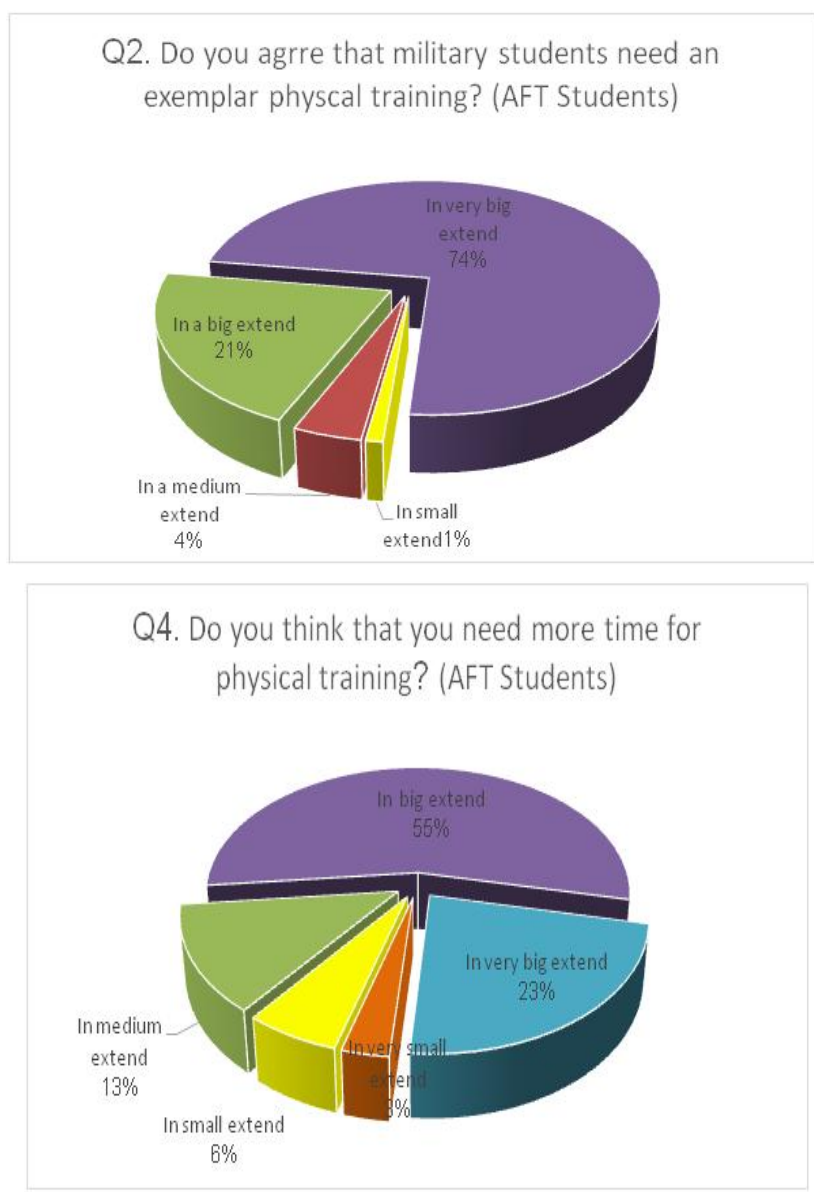

parameters, obtaining average scores of 3.89, improvements being welcomed. We can thus notice from this the special role that the physical training has according to the students' acceptance; we also notice their desire to have multiple and diversified training spaces.

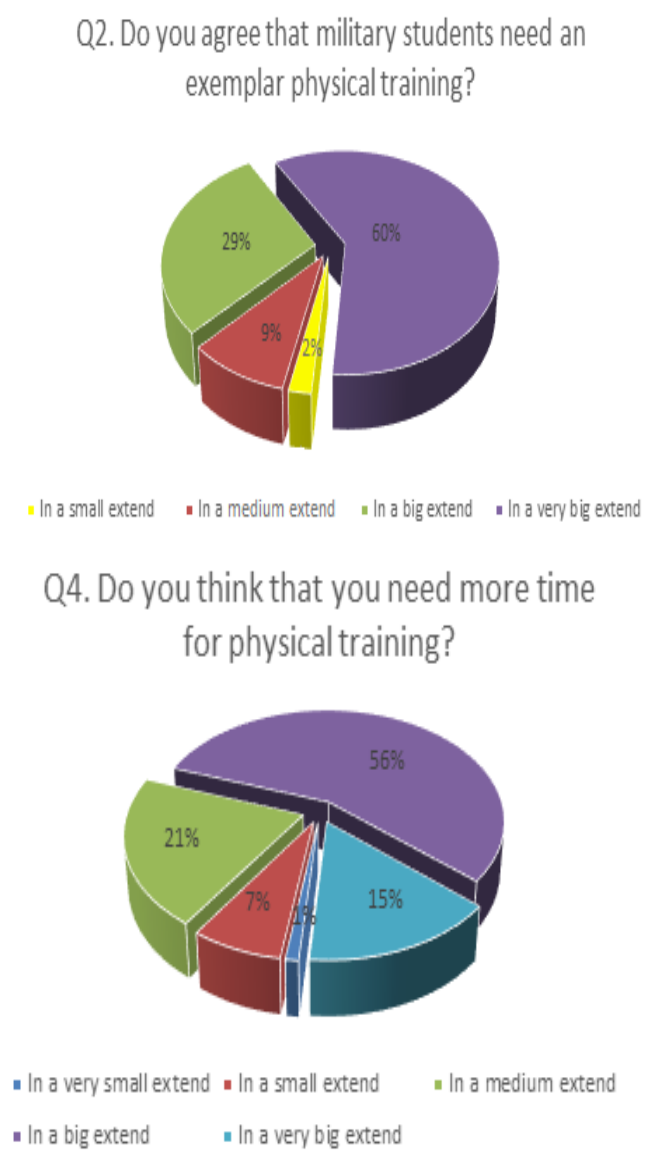

Figure no. 2: The answers of the students expressed in percentage to the questions no. 2 and no. 4

The following questions (nos. 7, 8, 9, 10 , and 12) aim to highlight the availability and benefits that practicing martial arts would offer to military students. Thus, we can notice the importance with which the combat sports make their presence felt by the question: "When you hear the words "martial arts" does it make a difference to you?", a small number of students being uninterested in this, having an average score of 2.52. The military students' willingness regarding self-defence courses is marked by item 8 "Would you like to practice martial arts as part of the academic program?", more than half answering "to a very large extent" and "to a large extent", highlighting an average score of 3.80 . These answers give the research credibility, thus validating the hypothesis that outlines the implementation of martial arts as part of the academic training. 


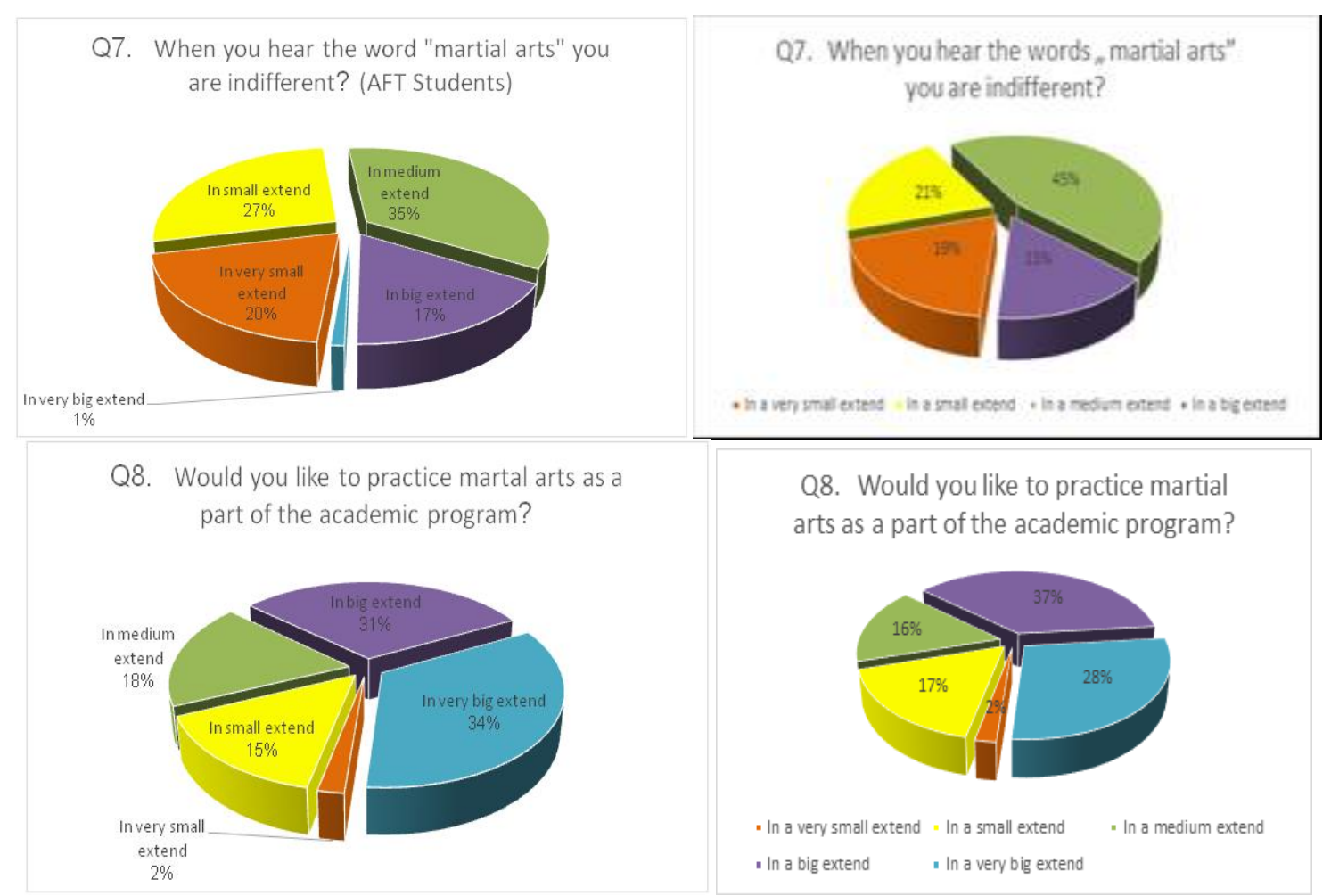

Figure no. 3: The answers of the students expressed as a percentage to the questions no. 7 and no. 8

When students were asked about the benefits that combat sports would offer them, they completed questionnaire replies so that at the time of analysis, the score of 4.19 for the students of the "Nicolae Bălcescu" Land Forces Academy was obtained and 3.70 for the students of the "General Milan Rastislav Štefánik" Academy of Armed Forces. Their influences have a significant impact on them. With their practice and initiation into the mysteries of a martial art, they will experience improvements in both physical and mental health.

Through the following items of this section, namely 11 and 14, it is emphasized that the students of the academy would like to practice a combat sport, as part of the academic program the question "Would you like to introduce a martial art in the academic program?", obtained the result 4.08. With the help of the following items in this section, namely 11 and 14 , it is revealed that the students of the academy would like to practice a combat sport, as part of the academic program, the question
"Would you want martial arts to be included in the academic program", obtaining the result 3.80. 29 students expressed their agreement regarding the conduct of activities choosing "to a very large extent", as well as a number of 37 students choosing "to a large extent".

The part dedicated to external factors starts with item number 16, "Do you think that martial arts bring a plus to the general physical training for military students", which highlights the strong influence felt by practitioners, improving their qualities and skills, obtaining an average score of 4.22 for students from the "Nicolae Bălcescu" Land Forces Academy in Sibiu and 3.94 for the students of the "General Milan Rastislav Štefánik" Academy of Armed Forces. The necessity to study a combat discipline formulated with the help of question no. 17, "Do you consider that military students have to study martial arts in order to defend themselves against potential aggressors without using a weapon?" reveals the general opinion of 
military students that it is beneficial to study a martial art so that the ability to react against possible aggressors to be as fast and efficient, without using the weapon, the average score being 4.28 for the Romanian students and 3.96 for the Slovak students.
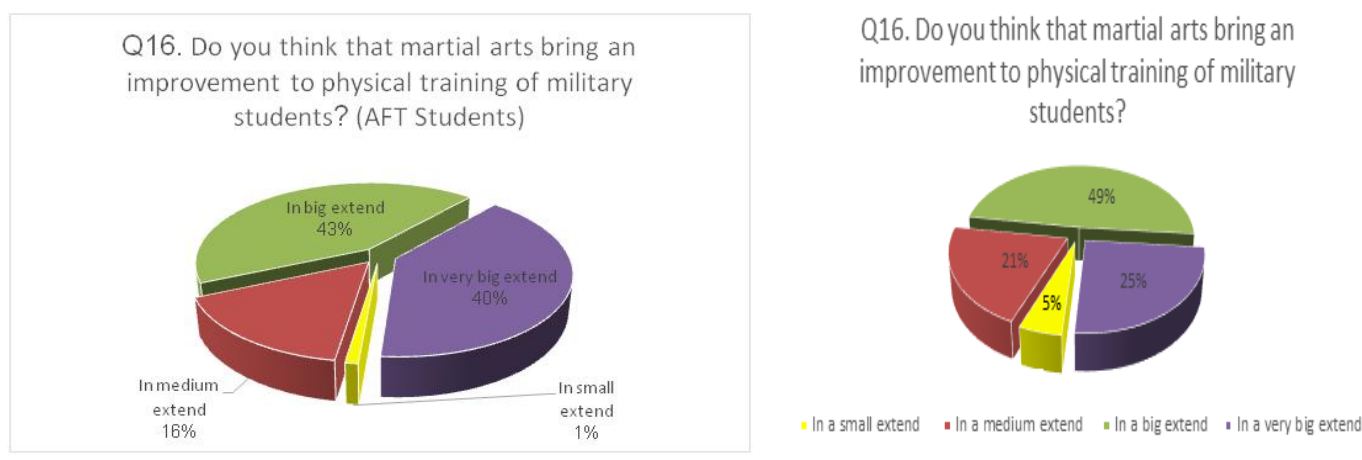

Figure no. 4: Question no. 16

Question no. 20 "Do you consider that in the military training, the emphasis falls less on the physical training, compared to the theoretical and the specialized one?", reveals the students' affirmative opinion, this part of the students considering that in the academy, the physical training is neglected in relation to the other study disciplines, the average score being 3.81. In order to be able to counter this event, the curriculum should be structured so that all subjects are covered, but at the same time, a balance between them is created.

Item no. 20 for the students, "Do you consider that in military training, the accent falls less on physical training, in comparison with the theoretical and specialty ones?" highlights the positive opinion of military students, who stated that in the academy, physical training is neglected in relation to the others study disciplines, the average score obtained being 3.58. In order to be able to counter this event, the curriculum should be structured so that all subjects are covered, but at the same time, a balance between them is created.

The last aspect analyzed, in the question no. 21, namely "Do you think that the introduction of martial arts in the academic program would increase the discipline, focus power and strength of the students" was confirmed, obtaining an average score of 4.15 at the "Nicolae Bălcescu" Land Forces Academy in Sibiu and a score of 3.94 at the "General Milan Rastislav Štefánik" Academy of Armed Forces.
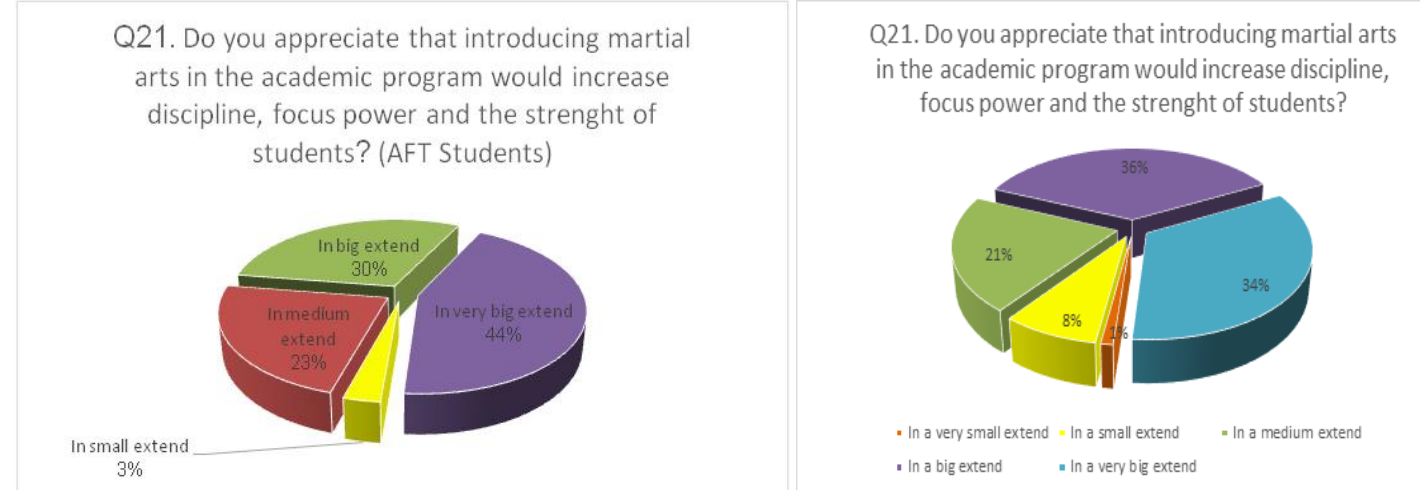

Figure no. 5: Question no. 21 


\section{Research Conclusions}

Drawing a comparative comparison between the two categories of students analyzed, the students of the "Nicolae Bălcescu" Land Forces Academy in Sibiu, as well as those of the "General Milan Rastislav Štefánik" Academy of Armed Forces, Slovakia, we can say that their answers show a high percentage of similarity, the most important issues outlined being:

$>$ item number 1 "Do you consider that physical training is important?" obtained high scores from both categories (4.68, respectively 4.49 in Slovakia), so we were made on the importance that physical training has for the students' perspective;

$>$ the third question, proves, from all students' involved perspective, that there is a discussion regarding the little importance that is given to physical training, followed by the time needed to be assigned to it, which is also considered to be insufficient (question no. 4);

students from both academies agreed on and were willing to have combat sports introduced in their academies' curriculum, a higher percentage coming from the Academy in Sibiu (because the students from Slovakia attend some self-defence modules, which is not the case for the students from Romania);

the contribution to physical and mental health due to martial arts training was noted by both camps; unlike the Slovak students who considered that the obligation to practice a combat sport is not so important (obtaining an average score of 3.75), the Romanian students were more convinced about this aspect, giving answers that summed up an average score of 4.16; also, regarding the physical training and its contribution in combating contemporary threats, LFA students again had a better score (3.78), raising awareness of the primary role of physical training, while Slovak students highlighted a score of 3.45;

last but not least, the contribution of martial arts was speculated by the students regarding the increase of discipline, focus power and strength, these obtaining average scores of 4.15, respectively, 3.94, again noticing the stronger opinion of the Romanian students;

it is desired to balance the emphasis placed on the physical training to the academic and specialized training.

Given these aspects, we note the need to focus academies on physical training, as well as on organizing complex, long-term and continuous body-to-body combat courses, so that beneficiaries have a complete and complex experience capable of making them more responsible in accordance with the demands of the contemporary environment. 


\section{REFERENCES}

Achim, A. (2005). Karate-do spirit şi filosofie. Sibiu: Editura Orient.

Chelcea, S. (2004). Iniţiere în cercetarea sociologică. Bucureşti : comunicare.ro.

Deliu, D. (2016). Tehnici de autoapărare. Cursuri și lecții practice. Bucureşti : Discobolul.

Harrison, M., \& Shirom, A. (1999). Organizational Diagnosis and Assessment: Bridging Theory and Practice. Modern Economy, Vol. 5, Issue 4, Thousand Oaks, SUA: Sage Publications.

Howell, L. (2003). Martial Arts and Confidence. Martial Artz, U.K.

Okazaki, T. (2009). Perfecţionarea caracterului : principii orientative pentru arte marţiale şi viaţa de toate zilele. Brașov : Transilvania Expres.

Petre, R. L. (2014). Combat. Bucureşti : Discobolul.

Weinberg, R. S., \& Gould, D. (1999). Foundations of Sport and Exercise Psychology $\left(2^{\text {nd }} e d.\right)$. Dunfermline, U.K.: Human Kinetics Pub. 